\title{
PHOSPHATE ESTER HYDROLYSIS PROMOTED BY AN AMIDOPYRIDINE CARBOXYLATE COMPLEX
}

\author{
Mery Napitupulu ${ }^{1, *}$, Daud K. Walanda ${ }^{1}$, Geoffrey. A. Lawrance ${ }^{2}$ \\ and Marcel. Maeder ${ }^{2}$ \\ ${ }^{1}$ Department of Chemistry Education, Universitas Tadulako, Palu, \\ Central Sulawesi 94118, Indonesia \\ ${ }^{2}$ Discipline of Chemistry, The University of Newcastle, NSW 2308, Australia \\ "E-mail: merytn@gmail.com
}

\begin{abstract}
The purpose of this study was to test the ability of the cobalt complex of ammonium cis-dichloro\{2-[N-(2'pyridylmethyl)carbamyl]pyridine-6-carboxylato $\}$ cobalt(III), $\quad$ and $\quad$ dichloro(1-(2'-pyridylmethyl)-1,5,9triazacyclododecane)cobalt(III)perchlorate, to act as a promoter of diester hydrolysis. The compound isolated by using metal directed syntheses procedure. The ability of kinetic recorded by Bio-Rad FTS7 spectrometer. Ammonium cisdichloro $\{2$-[N-(2'-pyridylmethyl) carbamyl] pyridine-6-carboxylato $\}$ cobalt(III), indicate the active compound to hydrolysis bis(4-nitrophenyl)phosphate (BNPP) with the rate constant $(\mathrm{k})=0.50 \times 10^{3} \mathrm{~min}^{-1}$, while dichloro(1-(2'pyridylmethyl)-1,5,9-triazacyclododecane) cobalt(III) perchlorate, does not promote ester hydrolysis.
\end{abstract}

Keywords: hydrolysis, BNPP, Ester, complex, compound, syntheses.

(C) RASĀYAN. All rights reserved

\section{INTRODUCTION}

Syntheses and metal complexation chemistry for hydrolysis and biological use has been studied. ${ }^{1-6}$ The hydrolysis of phosphodiesters, which are highly resistant to electron attack, is prominent because phosphodiester bonds from the backbone of DNA and RNA active catalysts of their hydrolysis showed its application in medical research. ${ }^{7}$ The catalytic hydrolysis of more reactive phosphor esters in relation with detox or abrupt withdrawal has also studied. ${ }^{8}$

It is reported that the binding of the model phosphodiester, bis(4-nitrophenyl)phosphate (BNPP), to the complex initially involved an attack by the activated hydroxyl group (from the pendant phenolate arm) at the phosphorus and the formation of a phosphoryl intermediate. ${ }^{9}$ The second step involves the intramolecular hydrolysis of the phosphoryl intermediate intramolecularly by the $\mathrm{Zn}^{\mathrm{II}}-\mathrm{OH}$ moiety. The majority of the initial $\mathrm{Zn}^{\mathrm{II}}$ complex was converted to the final product, where almost two equivalent of 4nitrophenolate was released. The complex was unreactive towards the hydrolysis of the phosphomonoester that was formed.

Even inert metal centers like cobalt(III) can promote ester hydrolysis, with the added advantage of complex inertness and diamagnetism assisting mechanistic elucidation. The first study of the hydrolysis of nitrophenyl phosphate by a known cobalt(III) complex reported showed the production of the $p$ nitrophenylate ion, as well as the release of the p-nitrophenyl phosphate ligand from $\left[\mathrm{Co}\left(\mathrm{NH}_{3}\right)_{5}\left(\mathrm{O}_{3} \mathrm{POC}_{6} \mathrm{H}_{4} \mathrm{NO}_{2}\right)^{+} .{ }^{10}\right.$ The phosphate ester hydrolysis of coordinated $p$-nitrophenyl phosphate in cis- $\left[\mathrm{Co}(\mathrm{en})_{2}(\mathrm{OH}) \mathrm{O}_{3} \mathrm{POC}_{6} \mathrm{H}_{4} \mathrm{NO}_{2}\right]$ with a rate enhancement of $10^{5}$ relative to that of the uncoordinated ester has also been reported, ${ }^{10}$ including the hydrolysis of a dimeric species, bis $(\mu-4-$ nitrophenylphosphate)bis[bis(1,2-ethylenediamine)cobalt(III)], which also shown a rate enhancement of $10^{5,11}$.

The mechanism reaction of $\mathrm{Co}$ (III) metal complexes and the study of steps for probing aspect of phosphate ester hydrolysis by $\mathrm{Co}$ (III)-catalyzed has been reported. ${ }^{12}$ It was interesting that $\mathrm{Co}$ (III) species use for promoting phosphate ester hydrolysis. ${ }^{13-14}$ That condition becomes factors of research development of catalysis which are capable to cleave the phosphate diester linkages within DNA ${ }^{15-16}$. 
The hydrolysis of phosphate diester by aquahydroxo(tetraamine) cobalt(III) complexes has shown rate enhancements of up to $10^{10}$ over the uncatalyzed rate. ${ }^{17}$ The hydrolysis rate the nature of the spectator tetraamine ligand in $\mathrm{Co}(\mathrm{III})$ complexes such as $\left[\mathrm{Co}(\operatorname{tren})\left(\mathrm{H}_{2} \mathrm{O}\right)(\mathrm{OH})\right]^{2+},\left[\mathrm{Co}(\text { cyclen })\left(\mathrm{H}_{2} \mathrm{O}\right)(\mathrm{OH})\right]^{2+}$, $\left[\mathrm{Co}(\operatorname{trpn})\left(\mathrm{H}_{2} \mathrm{O}\right)(\mathrm{OH})\right]^{2+}($ tren $=$ tris $(2$-aminoethyl $)$ amine; cyclen $=1,4,7,10$-tetraazacyclododecane; $\operatorname{trpn}=$ tris(3-aminopropylamine)amine shows the hydrolyses of BNPP at the respective rates of 1,28, 312 (pH 7.0, $\left.50^{\circ} \mathrm{C}\right) .{ }^{18}$

The use of Co(III) complexes in phosphate esters hydrolysis is non-catalytic, but stable in the intermediate reaction, and can be analyzed by its structure kinetically by ${ }^{18} \mathrm{O}$ labelling and ${ }^{31} \mathrm{P}$ NMR. $-{ }^{19}$ Such studies support a mechanism that involves; (i) water deprotonation and coordination; ${ }^{20-21}$ (ii) phosphate diester coordination to a metal ion; ${ }^{20-21}$ (iii) intramolecular attack; ${ }^{8}$ (iv) bonding cleavage of P-O. ${ }^{22}$

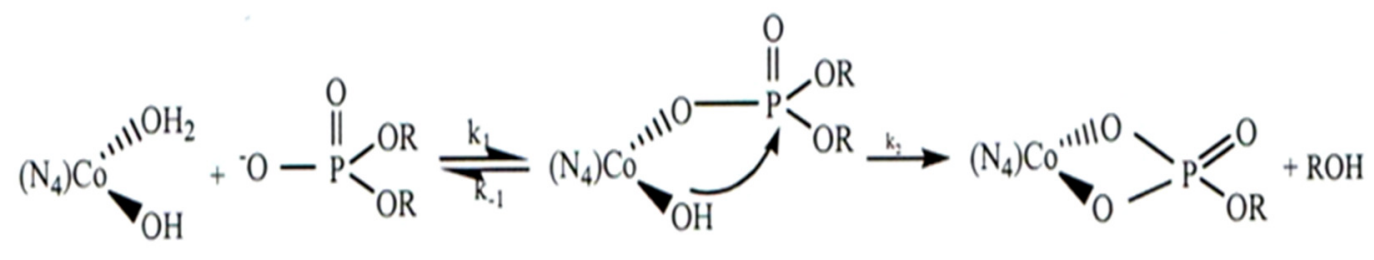

Scheme-1: Reaction mechanism of phosphate ester hydrolysis catalyzed by $\left[\mathrm{Co}\left(\mathrm{NH}_{3}\right)_{4}\right] \cdot \mathrm{H}_{2} \mathrm{O}$

Research of the rate enhancement nature has shown that the reaction undergoes via a four-membered ring intermediate containing the phosphate ester coordinated to the metal center. Presumably, the spectator tetraamine ligand is needed to accommodate the strained ring structure governs its formation and, as a consequence, the rate of ester hydrolysis influenced. ${ }^{23}$ The reaction mechanism for phosphate ester hydrolysis catalyzed by $\left[\mathrm{Co}\left(\mathrm{NH}_{3}\right)_{4}\right] \cdot \mathrm{H}_{2} \mathrm{O}$ complexes has been outlined in Scheme-1. ${ }^{24}$

Labile, paramagnetic systems, which may offer catalytic behavior, have been studied also. Tthe ability of mononuclear 1,4,7-triazacyclononane complex, $\left[\mathrm{Cu}(\operatorname{tacn}) \mathrm{Cl}_{2}\right]$, to hydrolyze a phosphate ester has been studied in detail. ${ }^{25}$ This complex was found to increase the rate of hydrolysis of a phosphodiester compared with the uncatalyzed reaction by 1000-fold and was specific for the hydrolysis of the phosphodiester, with the monoester hydrolysis 40 times slower than diester. ${ }^{26}$

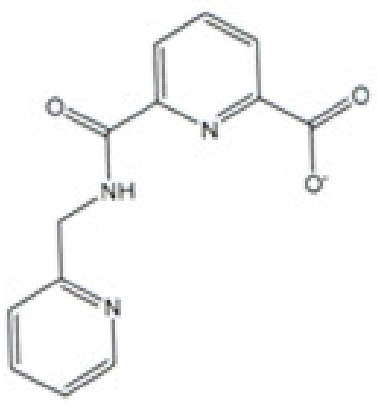

(1)

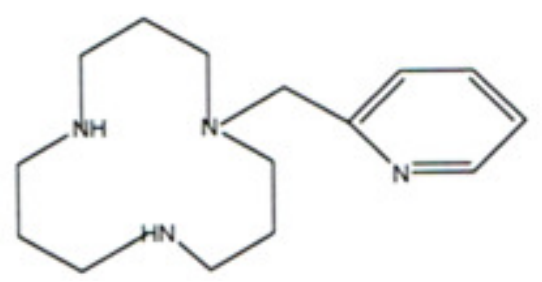

(2)

Fig.-1: Amidopyridine ligands

The pyridine-containing systems have been studied ${ }^{27-29}$, while amidopyridine carboxylates such as (1) and (2) (Fig. -1) have not been examined before, then this will come in this study.

\section{EXPERIMENTAL}

Syntheses of Ammonium cis-Dichloro\{2-[N-(2'-pyridylmethyl)carbamyl]pyridine- 6carboxylato $\}$ cobalt(III), [( $\left.\left.\left.\mathrm{NH}_{4}\right) \mathrm{Co}(7)-2 \mathrm{H}\right) \mathrm{Cl}_{2}\right]$

The monoester (1) and (2) were prepared as described. ${ }^{26-28}$. Sodium tris(carbonato)cobaltate(III) was prepared as previously described. ${ }^{27}$ To ligand $\mathrm{NH}_{4}(\mathbf{1})(1 \mathrm{~g}, 3.69 \mathrm{mmol})$ dissolved in acetone $(50 \mathrm{~mL})$, a 
solution of sodium tris(carbonato)cobaltate(III) $(1.58 \mathrm{~g}, 3.69 \mathrm{mmol})$ in water $(50 \mathrm{~mL})$ was added with stirring. The resulted brown solution was warmed $\left(50^{\circ} \mathrm{C}\right)$ and stirred overnight then diluted to $1 \mathrm{~L}$ with water and sorbed onto a column of Sephadex C-25 cation exchange resin ( $\mathrm{Na}^{+}$-form). The solution recovered after passing directly through the column was collected and evaporated to dryness, taken up ethanol, then filtered. Some brownish solid was collected and dried. The further anionic complex was collected of the cationic Sephadex column by washing with water alone, and was taken to a small volume then set aside for crystallization. A further small amount of brown solid, presumably the neutral peroxo species $\left.\mu-\left\{\left[\mathrm{H}_{2} \mathrm{O}\right) \mathrm{Co}(\mathbf{1})\right]_{2} \mathrm{O}_{2}\right\}$, formed after a few days. A small band was next removed with $0.1 \mathrm{M} \mathrm{NaCl}$ and rotary evaporated to dryness, dissolved in ethanol and solid $\mathrm{NaCl}$ removed by filtration, and the filtrate set aside for crystallization. After few weeks some purple crystals were collected, washed with a small amount of ethanol, then diethyl ether, and dried in a desiccator. Anal. C, 39.7, H, 3.45; N, 11.95\% $\mathrm{C}_{13} \mathrm{H}_{11.5} \mathrm{Cl}_{2} \mathrm{CoN}_{3.5} \mathrm{O}_{3}$ requires $\mathrm{C}, 39.5 ; \mathrm{H}, 3.2 ; \mathrm{N}, 12.4 \%$. NMR $\left(\mathrm{CDCl}_{3}\right){ }^{1} \mathrm{H}: \delta 2.01\left(4 \mathrm{H}\right.$, br s, $\left.\mathrm{NH}_{4}{ }^{+}\right), 4.80$ $\left(2 \mathrm{H}, \mathrm{d},-\mathrm{CH}_{2}-\right), 7.20(1 \mathrm{H}, \mathrm{ddd}, \mathrm{pyH}, 7.40(1 \mathrm{H}, \mathrm{dd}, \mathrm{pyH}), 7.70(1 \mathrm{H}, \mathrm{ddd}, \mathrm{pyH}), 8.01(1 \mathrm{H}, \mathrm{t}, \mathrm{pyH}), 8.33(1 \mathrm{H}$, $\mathrm{d}, \mathrm{pyH}), 8.36(1 \mathrm{H}, \mathrm{d}, \mathrm{pyH}), 8.53(1 \mathrm{H}, \mathrm{dd}, \mathrm{pyH}), 9.26(1 \mathrm{H}, \mathrm{t},-\mathrm{NH}-) .{ }^{13} \mathrm{C}: \delta 44.0,\left(-\mathrm{CH}_{2}-\right), 121.1,122.0 .124 .0$, 124.3. 136.5, 138.3, (pyCH), 148.2, 148.6, 156.3 (pyC $\mathrm{ptet}), 163.0,(\mathrm{C}=\mathrm{O}) \mathrm{ppm} . \mathrm{IR}\left(\mathrm{cm}^{-1}\right): 3380\left(\mathrm{NH}_{4}^{+}\right), 1685$ $\left(\mathrm{COO}^{-}\right) 1539(\mathrm{NHCO}), 1082,748,662$ (py). Electronic spectrum: $\lambda_{\max }\left(\varepsilon_{\max }\right): 351 \mathrm{~nm}(890), 472(176$ $\left.\mathrm{dm}^{3} \mathrm{~mol}^{-1} \mathrm{~cm}^{-1}\right)$.

\section{1-(2'-pyridylmethyl)-1,5,9-triazacyclododecane, (2)}

This ligand was prepared according to the method described, ${ }^{30}$ and characterized by spectroscopic comparison with an authentic sample.

\section{Dichloro(1-(2'-pyridylmethyl)-1,5,9-triazacyclododecane)cobalt(III) perchlorate, [Co(2)Cl $\left.\mathbf{C l}_{2}\right]\left(\mathrm{ClO}_{4}\right)$.}

To a solution of ligand (2) $(0.4 \mathrm{~g}, 1.49 \mathrm{mmol})$ in water $(100 \mathrm{~mL})$ was added cobalt(II) chloride hexahydrate $(0.35 \mathrm{~g}, 1.49 \mathrm{mmol})$. The resulted purple solution was warmed $\left(50{ }^{\circ} \mathrm{C}\right)$ and stirred overnight while air was bubbled through the solution for about 6 hours and then concentrated $\mathrm{HCl}(3 \mathrm{~mL})$ was added to the solution and it was left to stir for another night. The purple solution was diluted to $500 \mathrm{~mL}$ with water and sorbed onto a column of Dowex $50 \mathrm{~W} \times 2$ cation exchange resin. The column was washed with water and $1 \mathrm{M} \mathrm{HCl}$ to remove any unreacted cobalt and $3 \mathrm{M} \mathrm{HCl}$ used to remove the product. The major purple solution was rotary evaporated to a small volume and $1 \mathrm{M} \mathrm{HClO}_{4}(2 \mathrm{~mL})$ was added to the solution and it was set aside for crystallization. After a few weeks, some dark green crystals were formed and were collected by filtration. (0.18 g, 24\%). Anal. C, 36.4, $\mathrm{H}, 5.5 ; \mathrm{N}, 11.1 \% \mathrm{C}_{15} \mathrm{H}_{30} \mathrm{Cl}_{3} \mathrm{CoN}_{4} \mathrm{O}_{4}$ requires $\mathrm{C}, 36.5 ; \mathrm{H}, 5.3 ; \mathrm{N}$, $11.1 \% .{ }^{1} \mathrm{H}: \delta 1.89,2.40,3.06,3.32,7.75$ ppm. ${ }^{13} \mathrm{C}: \delta 17.6,20.6,23.6,41.0,47.4,48.5,49.4,54.7,62.0$, 78.7, (- $\left.\mathrm{CH}_{2}-\right), 121.3,126.0,141.9,152.4,161.9$ (pyCH) ppm. IR( $\left.\mathrm{cm}^{-1}\right): 1608$ (-NH-), 1085, 748, 662 (py). Electronic spectrum: $\lambda_{\max }\left(\varepsilon_{\max }\right): 354(78) 489\left(55 \mathrm{dm}^{3} \mathrm{~mol}^{-01} \mathrm{~cm}^{-1}\right)$.

\section{Physical Method \\ Spectroscopy}

The complexes compound was analyzed with NMR in $\mathrm{CDCl}_{3}$ solutions and $\mathrm{D}_{2} \mathrm{O}$ using a Bruker DPX300. FT-IR spectra analyzed on Nicolet Avatar 370 fitted with a golden gate accessory or a Bio-Rad FTS7 spectrometer.

\section{Kinetics}

Kinetic measurements were made on a Varian Cary Probe 50, equipped with a thermostatted cell holder. The temperature was regulated via an external circulating water bath. Chlorocobalt(III) complexes were reacted with a calculated amount of $\mathrm{AgNO}_{3}$ solution prior to use, and $\mathrm{AgCl}$ separated by filtration to leave aquacobalt(III) complexes. Complex solution was prepared at $10^{-3} \mathrm{M}$ in buffer solution for $\mathrm{pH}$ dependence measurement, and $7.5 \times 10^{-4}, 1 \times 10^{-3}, 1.5 \times 10^{-3}, 2 \times 10^{-3} \mathrm{M}$ for concentration dependence measurement. Buffer solutions were made by using $1 \mathrm{M}$ acetic acid, $0.2 \mathrm{M}$ phosphoric acid, and $1 \mathrm{M}$ TRIS as described. ${ }^{31}$ Seven different $\mathrm{pH}$ were used in this reaction; $4.1,5,6.5,7,8,8.9$ and 10 at $37^{\circ} \mathrm{C}$. BNPP solution used was made up and used as a concentrated active reagent (final concentration of BNPP $10^{-4} \mathrm{M}$ ). The rate of 4nitrophenylate formation was monitored spectrophotometrically at $400 \mathrm{~nm}$. Reactions were performed in 
glass cuvettes, fitted with a stopper, with a final volume of $2.4 \mathrm{~mL}$. Stock solution of $\left[\mathrm{Co}((1)-2 \mathrm{H})\left(\mathrm{H}_{2} \mathrm{O}\right)_{2}\right]^{+}$ in water $\left(2 \times 10^{-3} \mathrm{M}\right)$ were added to an equal volume of buffer $(\mathrm{pH} 8)$, ionic strength $0.1 \mathrm{M}$, to make the final concentration of $1 \times 10^{-3} \mathrm{M}$. For the $\mathrm{pH}$ dependence measurements, $2.3 \mathrm{~mL}$ of solution was placed into the cuvette, then the temperature was allowed to equilibrate for 10 minutes before the active reagent added. The stock solutions were made 10 times excess in BNPP. Reactions were generally followed for 2000 minutes for both concentration dependence and $\mathrm{pH}$ dependence measurements, with an absorbance reading taken every 2 minutes, or for shorter intervals and measurement intervals as required.

\section{Synthesis of Complexes}

\section{RESULTS AND DISCUSSION}

Reaction of $\left(\mathrm{NH}_{4}\right)(\mathbf{1})$ with tris(carbonato)cobalt(III) yields a brown anionic compound which is presumably $\left[\mathrm{Co}((1)-2 \mathrm{H})\left(\mathrm{CO}_{3}\right)\right]^{-}$, which undergoes hydrolysis and, in the presence of chloride ion, anation to produce $\left[\mathrm{Co}((\mathbf{1})-2 \mathrm{H}) \mathrm{Cl}\left(\mathrm{OH}_{2}\right)\right]$ and $\left[\mathrm{Co}((\mathbf{1})-2 \mathrm{H}) \mathrm{Cl}_{2}\right]$. The isolated purple crystalline solid, recovered in modest yields, appears to be an ammonium salt of the latter anion. The coordination of $((\mathbf{1})-2 \mathrm{H})^{2-}$ as a ligand presumably involves the geometry depicted below, where the pyridine and its substituents in the 2 and 6 positions bind in a plane to form a mer arrangement. The pyridylmethyl group is then required to bind in one of the other sites, either in the same plane as the 2,6-substituents or else perpendicular to it. This places the charged groups trans, and the 'vacant' $\mathrm{X}$ sites in cis dispositions, each opposite a pyridine group. Unfortunately, a crystal of X-ray quality was not obtained to confirm the stereochemistry (Fig. - 2).

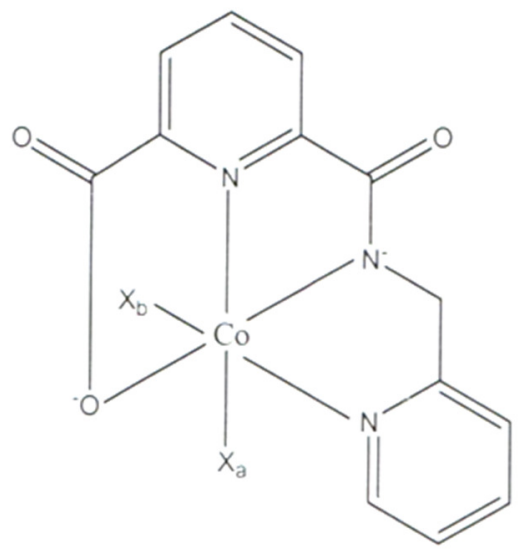

Fig.-2: Stereochemistry of $\left[\mathrm{Co}((\mathbf{1})-2 \mathrm{H}) \mathrm{Cl}\left(\mathrm{OH}_{2}\right)\right]$

However, the carboxylate-pyridine-amido unit, as inher structurally characterized complexes, will most likely have the ${ }^{-} \mathrm{O}-\mathrm{Co}-\mathrm{N}^{-}$bond bent back towards the pyridine due to its small 'bite', making coordination of the pendant pyridine in the alternate site $X_{a}$ unlikely due to excessive strain. Thus, when water groups are introduced at $X_{a}$ and $X_{b}$, the geometry is appropriate for diester coordination at one site and intramolecular attack from the other. Potentially, therefore, the complex of (1) may act to promote hydrolysis. However, the effect of the negative charges that exist on the ligand remains to be revealed. The pyridine-triamine (2) is another ligand which must bind to yield a cis disposition for the remaining two sites, as illustrated below (Fig.-3).

The two $\mathrm{X}$ groups will be inequivalent also, as in the case of (1), as one line trans to a tertiary $\mathrm{N}$, the other trans to a secondary $\mathrm{N}$ atom. The complex isolated was readily characterized as a $\left[\mathrm{Co}(2) \mathrm{Cl}_{2}\right]\left(\mathrm{ClO}_{4}\right)$ complex. Like the complex of (1), this has, as the hydroxy aqua species, the potential to promote diester hydrolysis.

\section{Hydrolytic Studies}

Complexes of (1) and (2) were tested as their aqua species (following $\mathrm{Ag}^{+}$-promoted hydrolysis of their chloro forms) for their ability to hydrolyze the activated phosphate diester, bis(4-nitrophenyl)phosphate. 
The initial reaction condition consisted of a solution containing $1.0 \mathrm{mM}$ of the complex, $0.1 \mathrm{mM}$ of BNPP in $100 \mathrm{mM}$ TRIS buffer at $\mathrm{pH}$ 8.0. The reactions were maintained at $37^{\circ} \mathrm{C}$ and were monitored for 2000 minutes, taking a single reading at $400 \mathrm{~nm}$ every 2 minutes. The data obtained from the initial screening experiments are shown in the Table- 1.

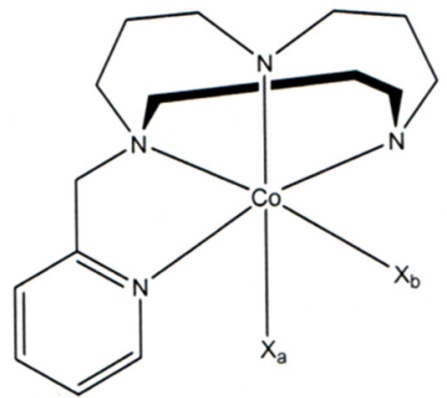

Fig.-3: Stereochemistry of $\left[\mathrm{Co}(2) \mathrm{Cl}_{2}\right]\left(\mathrm{ClO}_{4}\right)$

Table-1: Observed Rate Constant for Different Complexes Tested.

\begin{tabular}{c|c|c|c|c|c|c|c}
\hline Complex & Substrate & $\begin{array}{c}\lambda \\
(\mathrm{nm})\end{array}$ & $\begin{array}{c}\text { Temp } \\
\left({ }^{0} \mathrm{C}\right)\end{array}$ & $\mathrm{pH}$ & $\begin{array}{c}\text { Comp. } \\
\text { Conc. }\end{array}$ & $\begin{array}{c}\text { BNPP } \\
\text { Conc. }\end{array}$ & $\begin{array}{c}\mathrm{K}\left(\mathrm{min}^{-1}\right) \\
\times 10^{-3}\end{array}$ \\
\hline $\mathrm{Co}(1)(\mathrm{OH})\left(\mathrm{OH}_{2}\right)$ & BNPP & 400 & 37 & 8 & $1.0 \mathrm{mM}$ & $0.1 \mathrm{mM}$ & 0.50 \\
\hline $\mathrm{Co}(2)(\mathrm{OH})\left(\mathrm{OH}_{2}\right)$ & BNPP & 400 & 37 & 8 & $1.0 \mathrm{mM}$ & $0.1 \mathrm{mM}$ & No reaction \\
\hline
\end{tabular}

The rates for the hydrolysis of BNPP were calculated from the plots by the initial rates method. Other research groups have also used such a fitting procedure. ${ }^{10,32-35}$ The plot shows an increase in absorbance with time, the increase in absorbance being indicative of the hydrolysis of BNPP due to the release of the colored nitrophenylate ion. The plot in Fig.-4 shows that the complex $\left[\mathrm{Co}((\mathbf{1})-2 \mathrm{H})(\mathrm{OH})\left(\mathrm{H}_{2} \mathrm{O}\right)\right]$ tested in the study is an active compound to hydrolyzed BNPP indicating by the increasing of the absorbance vs. time. The rate constant $(\mathrm{k})=0.50 \times 10^{3} \mathrm{~min}^{-1}$ for $\left.\left[\mathrm{Co}((\mathbf{1})-2 \mathrm{H})(\mathrm{OH}) \mathrm{H}_{2} \mathrm{O}\right)\right]$ was obtained by a best fitting procedure. The reaction rates obeyed first-order kinetics $\left(\mathrm{R}^{2}>0.999\right.$ for all the complexes), and the pseudo-first-order rate constants $\left(\mathrm{k}_{\mathrm{obs}}\right)$ were obtained by a log plot method, and the second-order rate constant $\left(\mathrm{k}_{\mathrm{app}}\right)$ were estimated from the slopes of the linear plots $\left(R^{2}>0.999\right.$ for all the complexes) of $k_{\text {obs }}$ against the concentration of the complexes. ${ }^{36}$ Rate constants cited typically have errors of $\leq 10 \%$ applying.

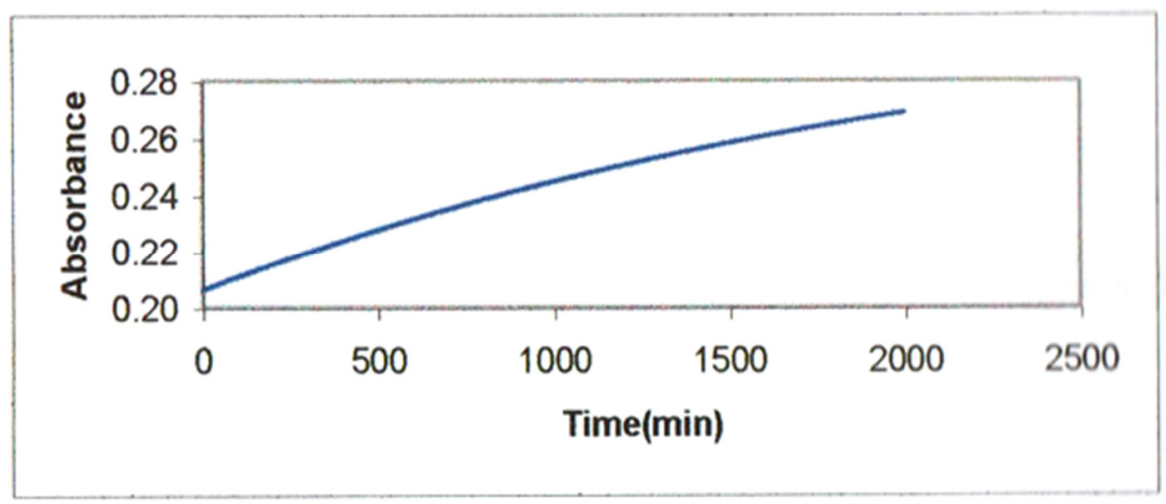

Fig.-4: Absorbance vs. time plot for the catalysis of BNPP by $\left[\mathrm{Co}((\mathbf{1})-2 \mathrm{H})(\mathrm{OH})\left(\mathrm{H}_{2} \mathrm{O}\right)\right]$ at $\mathrm{pH}$ 8.0, and temperature $37^{\circ} \mathrm{C}$.

The plot for the screening test of $\left[\mathrm{Co}(2)(\mathrm{OH})\left(\mathrm{H}_{2} \mathrm{O}\right)\right]^{2+}$ shows no absorbance increase with time. Rather, there is a small decrease in the absorbance vs. time plot (Fig.-5) which is most likely associated with an isomerization or anation reaction. Since it was clearly not associated with ester hydrolysis, this reaction was not investigated further. Why the complex of the $\mathrm{N}_{4}$-ligand (2) does not promote ester hydrolysis is 
unclear, given that a range of $\mathrm{N}_{4}$-ligands as spectators promote this chemistry. Possibly the larger chelate rings formed by the macrocycle, in this case, play some role, but at this stage speculation, on the basis of this single experiment, is not warranted.

Since the $\left[\mathrm{Co}((\mathbf{1})-2 \mathrm{H})(\mathrm{OH})\left(\mathrm{H}_{2} \mathrm{O}_{2}\right)\right]$ complex was found to be an active complex with which to hydrolyze BNPP, this studv will focus on the detailed analvsis of the kinetic behavior of this complex.

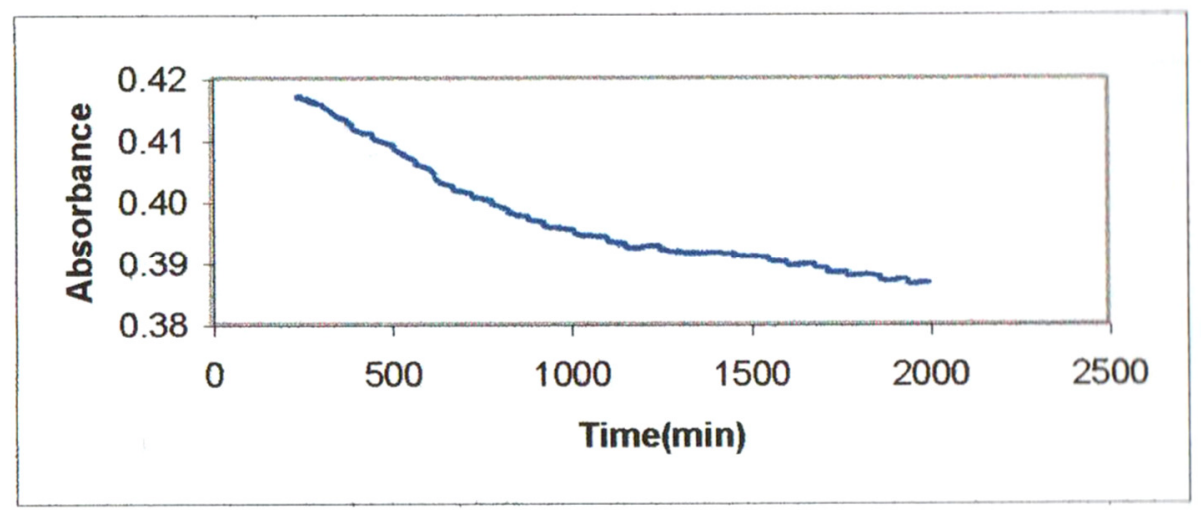

Fig.-5: Absorbance vs. time plot for the reaction of $\left[\mathrm{Co}\left((2)(\mathrm{OH})\left(\mathrm{H}_{2} \mathrm{O}\right)\right]\right.$ at $\mathrm{pH} 8.0$, temperature $37^{\circ} \mathrm{C}$.

\section{Kinetic Study of $\left[\mathrm{Co}((1)-2 \mathrm{H})(\mathrm{OH})\left(\mathrm{H}_{2} \mathrm{O}\right)\right]$ \\ Concentration Dependence}

Experiments were carried out with variation in complex concentration $(0.75,1,1.5,2.0$ and $3 \mathrm{mM})$, at temperature $37^{\circ} \mathrm{C}$ and $\mathrm{pH} 8.0$. The $\mathrm{pH}$ of the experiments was maintained through the use of TRIS buffers. The concentration of BNPP was kept constant at $0.1 \mathrm{mM}$, hence the complex was in large excess relative to the substrate $(\sim 7.5, \sim 10, \sim 15, \sim 20$ times $)$. The release of the 4-nitrophenylate anion was monitored at a single wavelength $(400 \mathrm{~nm})$ for a period of 2000 minutes. The resulting plots of absorbance versus time for various concentrations are shown in Fig.-6. The rise in the initial absorbance with concentration is related to absorbance by the complex itself.

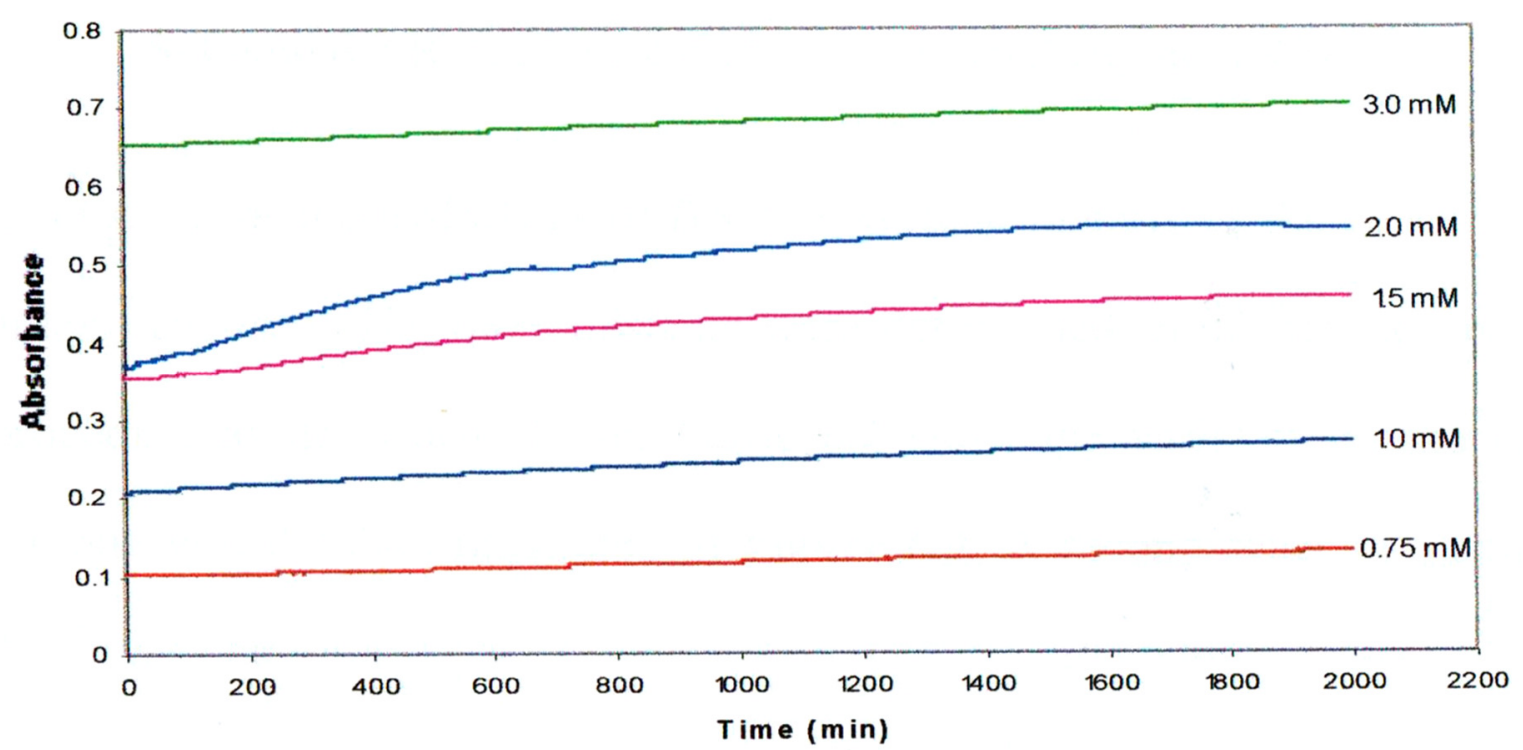

Hig.-6: 'Iypical plots of the absorbance increase over time at ditterent complex concentration due to the release of 4nitrophenylate. Conditions: temperature $=37^{\circ} \mathrm{C}, \mathrm{pH}=8,[\mathrm{BNPP}]=0.1 \mathrm{mM}$. 
In principle, the release of two 4-nitrophenylate (NP) ions may occur from BNPP as shown in Scheme-2. however, the hydrolysis of the diester occurs usually much more rapidly that of the monoester, i.e. $\mathrm{k}_{1}>>\mathrm{k}_{2}$. Data, in this case, was analyzed in terms of a single rate process successfully, although some non-ideal behavior was noted in some cases. However, this behavior was not reproducible, so a simple analysis was favored.

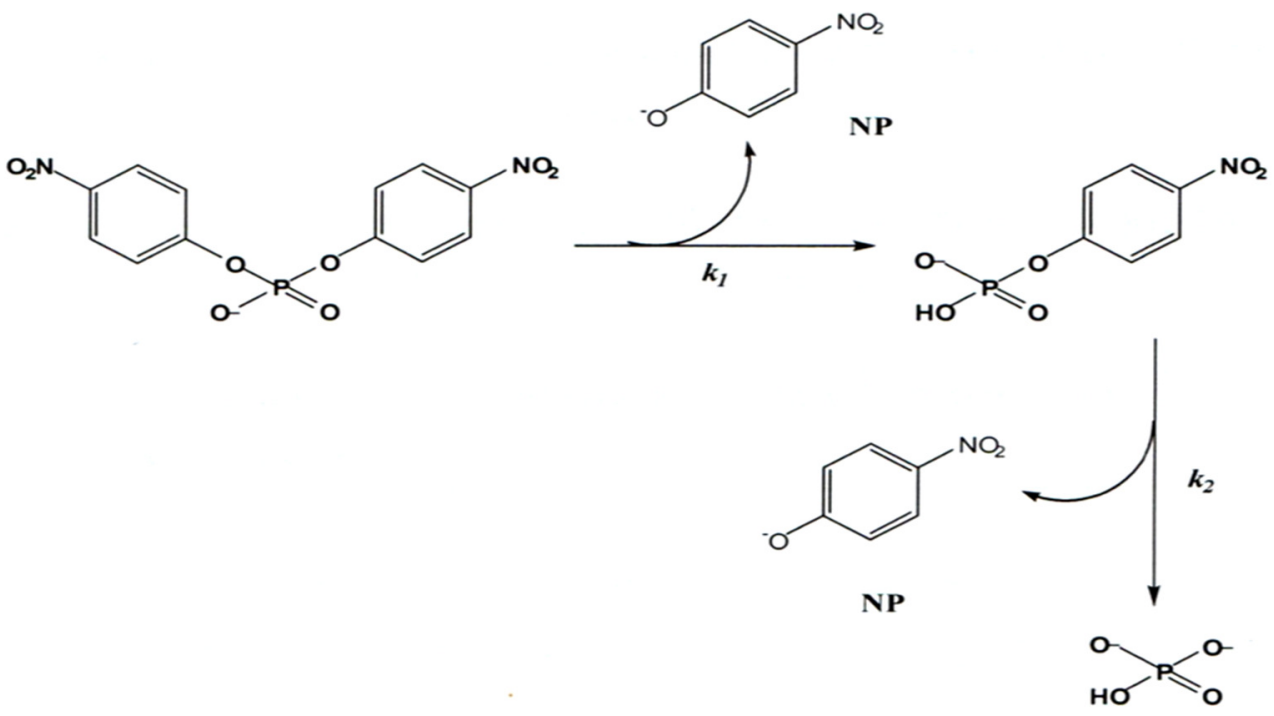

Scheme-2: The release of 2 moles of 4-nitrophenylate (NP). ${ }^{37}$

The rate constant for the hydrolysis of BNPP increased linearly as the concentration of the complex increased. The rate constants were determined from the data by the best fitting procedure as described above. Table- 2 shows the variation of the rate with concentration, with the data illustrated in Fig.-7. A second-order rate constant of $0.017 \mathrm{M}^{-1} \mathrm{~s}^{-1}$ was determined.

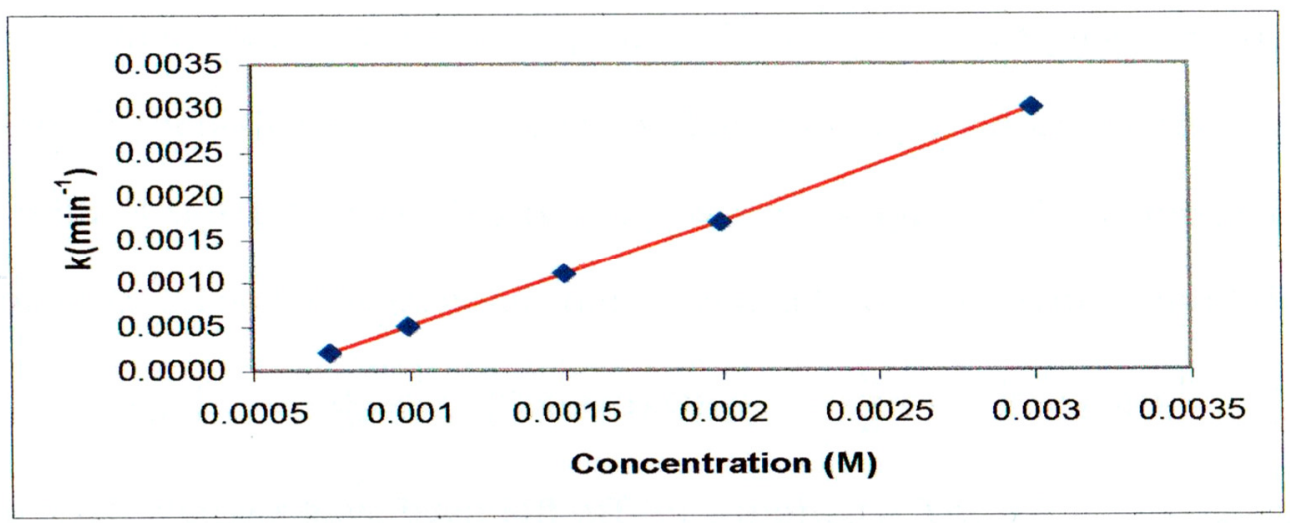

Fig.-7: Plot of concentration vs. rate constant for $\left[\mathrm{Co}((\mathbf{1})-2 \mathrm{H})(\mathrm{OH})\left(\mathrm{H}_{2} \mathrm{O}\right)\right]$ at $\mathrm{pH} 8.0$, and temperature $37^{\circ} \mathrm{C}$.

Table - 2: Rate constant for the hydrolysis of BNPP by $\left[\mathrm{Co}((\mathbf{1})-2 \mathrm{H})(\mathrm{OH})\left(\mathrm{H}_{2} \mathrm{O}\right)\right]\left(37^{\circ} \mathrm{C}, \mathrm{pH}=8,[\mathrm{BNPP}]=0.1 \mathrm{mM}\right)$

\begin{tabular}{c|c|c}
\hline $\begin{array}{c}\text { Complex } \\
\text { Concentration }\end{array}$ & Substrate & Rate Constant $\left(\mathrm{s}^{-1}\right) \times 10^{-5}$ \\
\hline $0.75 \mathrm{mM}$ & BNPP & 3.33 \\
\hline $1 \mathrm{mM}$ & BNPP & 8.33 \\
\hline $1.5 \mathrm{mM}$ & BNPP & 18.33 \\
\hline $2 \mathrm{mM}$ & BNPP & 28.33 \\
\hline $3 \mathrm{mM}$ & BNPP & 50.00 \\
\hline
\end{tabular}




\section{pH Dependence}

Experiments were carried out with variation in $\mathrm{pH}(4.1,5,6.5,7,8,8.9$, and 10$)$, at temperature $37^{\circ} \mathrm{C}$, $[\mathrm{BNPP}]=0.1 \mathrm{mM}$, [complex $]=1 \mathrm{mM}$. The $\mathrm{pH}$ was maintained through the use of buffers (TRIS, phosphate, and hydroxide) and was prepared according to literature. ${ }^{30}$ Rate constants at the various $\mathrm{pH}$ values are shown in Table-3. As seen from the table, generally, the rate constants increase as the $\mathrm{pH}$ increase up to $\mathrm{pH}$ $\sim 9$, then falls. A rate-pH profile is shown in Fig.-8 and shows the characteristic bell-shaped curve, comparable with that observed for the reaction of BNPP with $\left[\mathrm{Cu}\left(\mathrm{Me}_{3} \operatorname{tacn}\right)\left(\mathrm{H}_{2} \mathrm{O}\right)_{2}\right]\left(\mathrm{ClO}_{4}\right)_{2}$ which is typical for a process involving a deprotonation. ${ }^{37}$ The bell-shaped profile is related to the following Scheme:

$$
\left[\mathrm{CoL}\left(\mathrm{OH}_{2}\right)_{2}\right] \underset{\mathrm{H}^{+}}{\stackrel{\cdot \mathrm{H}^{+}}{\rightleftharpoons}}\left[\mathrm{CoL}(\mathrm{OH})\left(\mathrm{OH}_{2}\right)\right] \stackrel{\cdot \mathrm{H}^{+}}{\stackrel{\mathrm{H}^{+}}{\rightleftharpoons}}\left\lceil\mathrm{CoL}(\mathrm{OH})_{2}\right]
$$

Scheme-3: Equilibria of $\mathrm{pH}$ dependence

Where overall charges have been left for simplicity. The dihydroxo species dominant at high $\mathrm{pH}$ is inactive due to the very slow exchange of the hydroxide ions, making a substitution by the diester very slow. The diaqua complex formed at low $\mathrm{pH}$ can undergo more rapid ligand exchange, but the coordinated water is poor nucleophile. In the intermediate $\mathrm{pH}$ region, the aquahydroxo species is most successful, since substitution at one site is relatively rapid and the other site carries an efficient nucleophile for the intermolecular attack.

Table - 3: Rate constant for the hydrolysis of BNPP by $\left[\mathrm{Co}((\mathbf{1})-2 \mathrm{H})(\mathrm{OH})\left(\mathrm{H}_{2} \mathrm{O}\right)\right]\left(37^{\circ} \mathrm{C},[\mathrm{complex}]=1 \mathrm{mM},[\mathrm{BNPP}]\right.$ $=0.1 \mathrm{mM})$.

\begin{tabular}{c|c}
\hline $\mathrm{pH}$ & Rate Constants $\left(\mathrm{s}^{-1}\right) \times 10^{-5}$ \\
\hline 4.1 & 5.00 \\
\hline 5.0 & 6.66 \\
\hline 6.5 & 11.66 \\
\hline 7.0 & 16.66 \\
\hline 8.0 & 28.33 \\
\hline 8.9 & 30.00 \\
\hline 10 & 25.00 \\
\hline
\end{tabular}

The fully confirm this observation, the reaction would need to be monitored for a wider range of $\mathrm{pH}$ values, or a more detailed study of the hydrolysis of BNPP by $\left[\mathrm{Co}((\mathbf{1})-2 \mathrm{H})(\mathrm{OH})\left(\mathrm{H}_{2} \mathrm{O}\right)\right]$ need to be undertaken. Time constraints prevented that here.

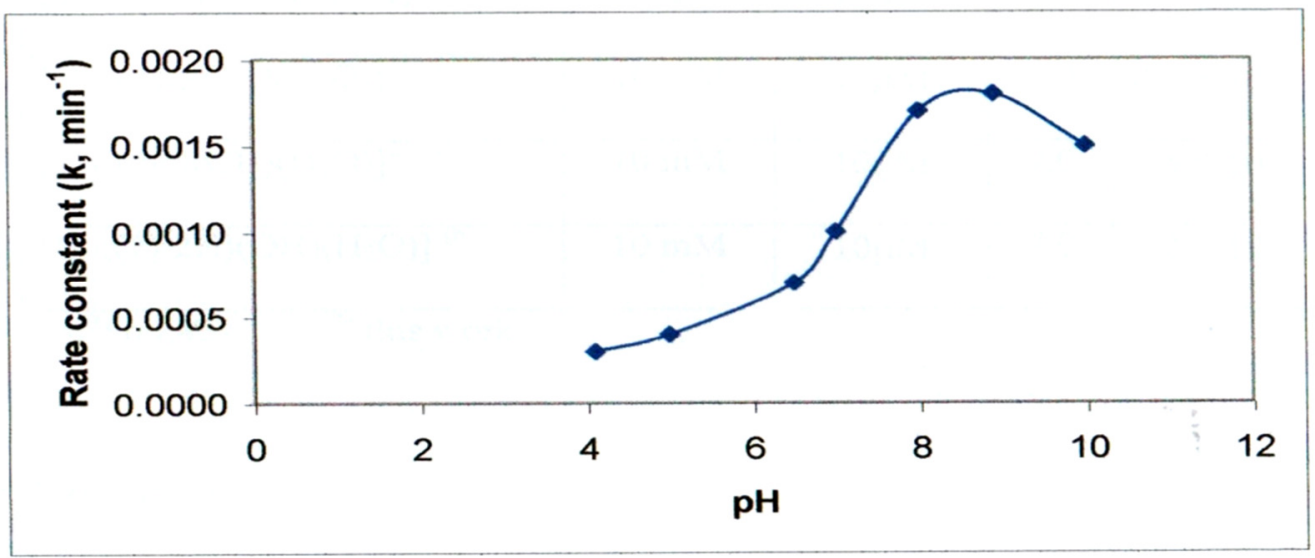

Fig.-8: Rate constant versus $\mathrm{pH}$ for the hydrolysis of BNPP by $\left[\mathrm{Co}((1)-2 \mathrm{H})(\mathrm{OH})\left(\mathrm{H}_{2} \mathrm{O}\right)\right]$ 


\section{RASĀYAN J. Chem.}

Vol. 11 | No. 2 |894 - 903 | April - June | 2018

Comparison of the observed first-order rate constant for the hydrolysis of BNPP by various cobalt complexes is shown in Table-4. The complex of the $\mathrm{N}_{3} \mathrm{O}$ dianion ligand (1)-2H is less effective than those of the neutral $\mathrm{N}_{4}$ ligands trpn and cychlen, but superior to that tren. Despite the distinctly different ligand type, comparable acceleration occurs. The role of strain in the complexes cannot be discussed due to the absence of structural data for the complex of (1), but may play a role. Further, the maximum in the rate-pH profile appears to be shifted to higher $\mathrm{pH}$ with the dianionic ligand than is the case with saturated amines, associated with electronic effects of the ligand changing. That it is harder to deprotonate a water group in the presence of anionic ligands is not surprising.

Table-4: Observed first-order rate constants for the hydrolysis of BNPP by various cobalt(III) complexes at $50^{\circ} \mathrm{C}$

\begin{tabular}{|c|c|c|c|c|}
\hline Complex & [Complex] & [Substrate] & $\mathrm{pH}$ & Rate $\left(\mathrm{s}^{-1}\right)$ \\
\hline$\left[\mathrm{Co}(\text { cyclen })(\mathrm{OH})\left(\mathrm{H}_{2} \mathrm{O}\right)_{2}\right]^{2+(a)}$ & $10 \mathrm{mM}$ & $10 \mu \mathrm{M}$ & 7.0 & $4.6 \times 10^{-3}$ \\
\hline$\left[\mathrm{Co}(\operatorname{tren})(\mathrm{OH})\left(\mathrm{H}_{2} \mathrm{O}\right)\right]^{2+(a)}$ & $10 \mathrm{mM}$ & $10 \mu \mathrm{M}$ & 7.0 & $8.1 \times 10^{-5}$ \\
\hline$\left[\mathrm{Co}(\operatorname{trpn})(\mathrm{OH})\left(\mathrm{H}_{2} \mathrm{O}\right)\right]^{2+(a)}$ & $10 \mathrm{mM}$ & $10 \mu \mathrm{M}$ & 7.0 & $2.5 \times 10^{-2}$ \\
\hline$\left[\mathrm{Co}((1)-2 \mathrm{H})(\mathrm{OH})\left(\mathrm{H}_{2} \mathrm{O}\right)\right]^{(\mathrm{b})}$ & $10 \mathrm{mM}$ & $10 \mu \mathrm{M}$ & 7.0 & $1.2 \times 10^{-3}$ \\
\hline
\end{tabular}

\section{CONCLUSION}

First-order rate constants for the first step in the hydrolysis of BNPP by $\left[\mathrm{Co}((\mathbf{1})-2 \mathrm{H})(\mathrm{OH})\left(\mathrm{H}_{2} \mathrm{O}\right)\right]$ have been measured. The rate constants show a first-order dependence on the concentration of the complex, and with $\mathrm{pH}$ display a classical bell-shaped behavior which is typical of a process where two deprotonations take place. The anionic $\mathrm{N}_{3} \mathrm{O}$ ligand promotes cleavage to a very similar level to neutral $\mathrm{N}_{4}$ ligands, and represents the first example of a ligand without saturated amine donors in this role. The results, although limited, are sufficiently interesting to suggest a more detailed analysis should be conducted. This study identifies another role for amidopyridine ligands, some complexes of which have been previously shown to have catalytic roles in a number of diverse reactions.

\section{REFERENCES}

1. M. Komiyama, N. Takeda, H. Shigekawa, Chemical Communications.,1443(1999), DOI: 10.1039/A901621J.

2. M. Napitupulu, M.Sc. Thesis, Department of Chemistry, University of Newcastle, New South Wales, Australia (1999).

3. S. Chakrabarti, P.K. Patra, Rasayan Journal of Chemistry, 9(4), 627(2016), DOI: 10.7324/rjc.2017.1041741.

4. M. Napitupulu, Ph.D. Thesis, Department of chemistry, University of Newcastle, New South Wales, Australia (2006)

5. R.S. Subrahmanyam, P. Ramesh, B.S. Krishna, S. Swaroop, M.A. Khan, M.M. Darla, K. Adeppa, B.V. Bhaskar, W. Rajendra, V.R. Anna, Rasayan Journal of Chemistry, 10(4), 1194 (2017), DOI: 10.7324/RJC.2017.1041838.

6. M. Manorajani, T.B. Kumar, Rasayan Journal of Chemistry, 10(2), 333(2017), DOI: 10.7324/RJC.2017.1021625.

7. M. Galina, E. Viryasovaa, S. Golenkinaa, T.I. Galkinaa, Y. Gaponovab, M. Romanovac, F. Sud'ina, Biochimie, 125, 140(2016), DOI: 10.1016/j.biochi.2016.03.010

8. P. Scrimin, G. Ghirlanda, P. Tecilla, R. A. Moss, Langmuir, 12, 6235 (1996), DOI:10.1021/la960311g.

9. E. Kimura, Y. Kodama, T. Koike, M. Sihiro, Journal of American Chemical Society, 117, 8304 (1995), DOI: $10.1021 / \mathrm{ja} 00137 \mathrm{a} 002$

10. J. M, B. Harrowfield, D. R. Jones, L. F. Lindoy, A. M. Sargeson, Journal of American Chemical Society, 102, 7733 (1980), DOI: 10.1021/ja00546a016.

11. D. R. Jones, L. F. Lindoy, A. M. Sargeson, Journal of American Chemical Society, 105, 7327 (1983), DOI: $10.1021 / \mathrm{ja} 00363 \mathrm{a} 021$.

12. D. R. Jones, L. F. Lindoy, A. M. Sargeson, Journal of American Chemical Society, 106, 7807 (1984). DOI: $10.1021 / \mathrm{ja} 00337 \mathrm{a} 026$. 
RASĀYAN $J$. Chem.

Vol. 11 | No. 2 |894 - 903 | April - June | 2018

13. P. Hendry, A. M. Sargeson, Progress in Inorganic Chemistry, 3, 201 (1999), DOI: 10.1002/9780470166390.ch4.

14. I. M. Atkinson, L. F. Lindoy, Coordination Chemistry Reviews, 200-202, 207 (2000), DOI: 10.1016/s0010-8545(00)00255-1.

15. N. H. Williams, A. M. Lebuis, J. Chin, Journal of American Chemical Society, 121, 3341 (1999), DOI: 10.1021/ja9827797.

16. N. H. Williams, B. Takasaki, M. Wall, J. Chin, Accounts of Chemical Research, 34, 2412 (1999), DOI: 10.1021/ar9500877.

17. J. Chin, M. Banaszczyk, Journal of American Chemical Society, 111, 4103 (1989), DOI: 10.1021/ja00189a062.

18. J. Chin, M. Drouin, A. G. Michel, Acta Crystallographica, C46, 1022 (1990), DOI: 10.1107/s0108270189013314.

19. T. Itoh, H. Hisada, Y. Usui, Y. Fujii, Inorganica Chimica Acta 51, 283 (1998), DOI: 10.1016/s00201693(98)00222-9.

20. J. Chin, Accounts of Chemical Research, 24, 145 (1991), DOI: 10.1021/ar00005a004.

21. J. H. Kim, J. Chin, Journal of American Chemical Society, 114, 9792 (1992), DOI: 10.1021/ja00051a011.

22. P. Hendry, A. M. Sargeson, Journal of American Chemical Society, 111, 2521 (1989), DOI: 10.1021/ja00189a025.

23. P.V. Bernhardt, G.A. Lawrance, M. Napitupulu, G. Wei, Inorganica Chimica Acta, 300, 604 (2000), DOI: 10.1016/S0020-1693(00)00022-0.

24. J. Chin, M. Banaszczyk, V. Jubian, X. Zou, Journal of American Chemical Society, 111, 186 (1989), DOI:10.1021/ja00183a029.

25. P. Hendry, A. M. Sargeson, Journal of American Chemical Society, 29, 92(1990), DOI: 10.1021/ic00326a020.

26. J. Burstyn, K. Deal, Inorganic Chemistry, 32, 3585 (1993), DOI: 10.1021/ic00069a005.

27. N.W Alcock, G. Clarkson, P.B. Glover, G.A. Lawrance, P. Moore, M. Napitupulu, Dalton Transactions, 3, 518 (2005), DOI: 10.1039/b414251a.

28. M. Napitupulu, B.L. Griggs, S.X. Luo, P. Turner, M. Maeder, G.A. Lawrance, Journal of Heterocyclic Chemistry, 46(2), 243 (2009), DOI: 10.1002/jhet.72.

29. M. Napitupulu, G.A. Lawrance, G.J. Clarkson, P. Moore, Australian journal of chemistry 59(11), 796 (2006), DOI: 10.1071/CH06310.

30. M. Napitupulu, M. Rossignoli, G.A. Lawrance, M. Maeder, P. Turner, Transition Metal Chemistry, 32(3), 287 (2007), DOI: 10.1007/s11243-006-0158-2.

31. D. D. Perrin, Australian Journal of Chemistry, 16, 572 (1963), DOI: 10.1071/ch9630572.

32. K. Deal, J. Burstyn, Inorganic Chemistry, 35, 2792 (1996), DOI: 10.1021/ic9514881.

33. A. Bencini, E. Berni, A. Bianchi, V. Fedi, C. Giorgi, P. Paoletti, B. Valtancoli, Inorganic Chemistry, 38, 6323 (1999), DOI: 10.1021/ic990820g.

34. C. Bazzicalupi, A. Bencini, A. Berni, V. Fedi, V. Fusi, C. Giorgi, P. Paoletti, B. Valtancoli, Inorganic chemistry, 38, 4115 (1999), DOI: 10.1021/ic9902929.

35. E. Kimura, H. Hashimoto, T. Koike, Journal of American Chemical Society, 118, 10963 (1996), DOI: 10.1021/ja961789\%2B.

36. T. Itoh, H. Hisada, Y. Usui, Y. Fujii, Inorganica Chimica Acta, 283(1), 51 (1998), DOI: 10.1016/S0020-1693(98)00222-9.

37. F. H. Fry, Ph.D. Thesis, Monash University, Victoria, Australia, (2002).

[RJC-2060/2016] 